\title{
ISOLATION AND IDENTIFICATION OF FUNGI ASSOCIATED WITH COMPOSTING PROCESS OF MUNICIPAL BIOSOLID WASTE
}

\author{
Pham Thi Thu Hang ${ }^{\bowtie}$, Le Thi Quynh Tram, Tran Phuong Anh, Ho To Thi Khai Mui, Dang Nguyen \\ Thao Vi, Dinh Hoang Dang Khoa
}

Institute for Environment and Resource (IER), Vietnam National University Ho Chi Minh City

${ }^{凶}$ To whom correspondence should be addressed. E-mail: thuhangp@gmail.com

Received: 28.11 .2017

Accepted: 28.12.2017

\section{SUMMARY}

Organic waste is gradually degraded during composting process, producing carbon dioxide, water, heat, and humus, the relatively stable end product. The degradation process is carried out by living organisms, of which fungi appear to have the most important role since they break down tough debris (cellulose, lignin, and other resistant materials), enabling other microorganisms to continue the decomposition process. The objective of this study was to isolate and identify the fungi associated with large scale municipal biosolid waste composting process in Vietnam. In this study, we have isolated 10 morphologically different fungal strains from the composting materials, and classified based on morphological characteristics and 18S rDNA sequences. The results showed that these fungal strains belonged to four different genera, including Aspergillus, Penicillium, Monascus, and Trichoderma. The results would be a useful reference for further studies of diversity, and functions of fungi that involved in municipal biosolid waste composting process in Vietnam environmental conditions.

Keywords: Composting, fungal biodiversity, morphological classification, $18 S$ rDNA

\section{INTRODUCTION}

Composting technology has been widely used to treat biosolid waste, producing fertilizer for soil. The process is based on activities of variety of microorganisms, among those fungi play important roles due to their ability to degrade a wide range of ligno-cellulosic materials (Kumar et al., 2008), the major component of plant cells and the most abundant renewable organic resource. The lignocellulosic materials are composed of three types of polymers, namely cellulose, hemicelluloses, and lignin which are strongly engaged and persistent (Howard et al., 2003). In municipal biosolid wastes, ligno-cellulosic materials such as paper, carton, vegetable, and garden wastes are the major components. During composting process, fungi involve mainly at first (starting) mesophilic, and second (curing) mesophilic phase due to their low heat tolerance in comparing with bacteria (Insam, de Bertoldi, 2007). Fungi of genera Aspergillus, Microsporium, Trichophyton, Yeast, Mucor, Penicillium, Rhizopus, Fusarium, Cladosporium, and
Curvularia were reported dominant in composting process of forest litter (Song et al., 2010), rice straw (Hefnawy et al., 2013), and household waste (Dehghani et al., 2012). However, little is known about main fungal groups existing in municipal biosolid waste composting at industrial scale in environmental conditions of Vietnam. Therefore, the objective of this study was to isolate and identify fungi which are associated with industrial scale municipal biosolid waste composting process.

\section{MATERIALS AND METHODS}

\section{Sample collection}

Compost samples were collected at municipal waste composting factory in Binh Duong province. At the factory, the municipal biosolid waste underwent composting process in 100 ton piles with continuous aerating. The compost samples were collected at the surface and $25-\mathrm{cm}$ depth of a composting pile at the $1^{\text {st }}, 10^{\text {th }}, 20^{\text {th }}, 25^{\text {th }}, 35^{\text {th }}, 42^{\text {th }}$ day during composting process, and finished 
compost material (app. $90^{\text {th }}$ day). The samples were quickly transported to laboratory for analyzing. Temperature of each sampling point was recorded with a thermometer.

\section{Isolation and morphological classification}

Three gram of composting material was suspended in $27 \mathrm{~mL}$ of $0.9 \% \mathrm{NaCl}$ solution for 30 min with gently shaking at $200 \mathrm{rpm}$. After that, 100 $\mu \mathrm{L}$ of three consecutive dilutions was pipetted onto and spread evenly over petri plates containing Potato Glucose Agar (PGA) medium supplemented with chloramphenicol $(100 \mathrm{mg} / \mathrm{L})$, then incubated at $32^{\circ} \mathrm{C}$, in the dark for 5 to 7 days. Single colonies were picked up and streaked on new PGA plates. After 2 days when the colonies visibly grew, but conidia had not yet been produced, $5 \mathrm{~mm}$-diameter agar plugs were taken at the actively growing edge of the colony and transferred to fresh GPA plates, put in the position mycelia-side-down and at a distance of approximately $1.5 \mathrm{~cm}$ from the edge (or center) of the plates. Colony characteristics such as colony radius, colony appearance, time of first appearance of conidia, and type of pigmentation in the medium or conidia were recorded. Macromorphological observation was carried out within 1 week. Micro-morphological characteristics such as vigorous growth of mycelium structure, conidiophore, phialide and conidia were recorded for 3-5 day old pure-cultures, depending on the growth rate of strains by using slide culture method and lactophenol cotton blue stain following Benson's procedure (Benson, 2002). The purified strains were classified based on their macro- and micromorphological characteristics (Domsch et al., 1980).

\section{Genomic DNA extraction}

Genomic DNA of fungal strains was extracted using a modified method of Feng et al. (2010). From cultures on PGA plates, $20 \mathrm{mg}$ of fungal mycelia was collected into $1.5 \mathrm{~mL}$ tubes containing $0.2 \mathrm{~g}$ glass bead $(0.1 \mathrm{~mm}$ diameter), and $650 \mu \mathrm{L}$ of lysis buffer $(100 \mathrm{mM}$ Tris-HCl, pH 8.0; 50 mM EDTA, pH 8.0; $1 \%$ SDS; $10 \mu \mathrm{g} / \mathrm{mL}$ RNase A). The mixture was vortexed for $2 \mathrm{~min}$, then centrifuged at 10,000 $\mathrm{rpm}$ for $5 \mathrm{~min}$. After centrifugation, $500 \mu \mathrm{L}$ of supernatant was transferred into a new tube containing $100 \mu \mathrm{L}$ of sodium acetate buffer (3.0 M, $\mathrm{pH} 5.5$ ), and $500 \mu \mathrm{L}$ of isopropanol, mixed and centrifuged at $10,000 \mathrm{rpm}$ for $5 \mathrm{~min}$ to precipitate fungal DNA. DNA pellets were washed with $70 \%$ ethanol, air dried, then dissolved in $50 \mu \mathrm{L}$ of sterile distilled water. The quality of extracted DNA samples was tested by spectrophotometer and gel electrophoresis.

\section{Polymerase chain reaction (PCR) to amplify $18 \mathrm{~S}$ rDNA}

A variable region (app. 750 bp length) of $18 \mathrm{~S}$ rDNA gene was amplified with primer pair NS1 (5' - TAGTCATATGCTTGTCTC - 3') (White et al., 1990) and Fung5 (5, GTAAAAGTCCTGGTTCCCC - 3') (Smit et al., 1999). The PCR mixture $(25 \mu \mathrm{L})$ contained approximately $50 \mathrm{ng}$ of template DNA, 0.5 U DNA Taq-polymerase (MyTaq-Thermo scientific), 1× MyTaq PCR reaction buffer (MyTaq-Thermo scientific), and 20 pmol of each primer. A thermocycling was performed using a MyCycler Thermal cycler (Bio-Rad, UK) as follows: $94^{\circ} \mathrm{C} / 5$ min, followed by 30 cycles of $\left(94^{\circ} \mathrm{C} / 30 \mathrm{~s}, 47^{\circ} \mathrm{C} / 40 \mathrm{~s}\right.$, $72^{\circ} \mathrm{C} / 90$ s), then $72^{\circ} \mathrm{C} / 5 \mathrm{~min}$. After that, PCR products were analyzed by electrophoresis on $1.5 \%$ agarose gel, stained and observed under UV light.

\section{S rDNA Sequencing and Phylogenetic tree building}

PCR products were purified and sequenced by ABI PRISM ${ }^{\circledR}$ 3730XL Analyzer (Macrogen sequencing service). The obtained sequences were then analyzed with Bioedit version 7.25 software and compared with $18 \mathrm{~S}$ rDNA sequences available at NCBI database using Basic Local Alignment Search Tool (BLAST). The distance matrix for all pairwise sequence alignments was analyzed with the neighbor-joining $(\mathrm{NJ})$ method of phylogenetic tree construction with 1,000 bootstrap replicates by using MEGA version 6 software.

\section{RESULTS}

\section{Fungi isolation and classification}

From the samples collected at different stages of composting process, 10 fungal strains of different colony morphology were purified. Detail analyses of macro- and micro-morphological characteristics showed that these 10 fungal strains belonged to 4 genera, including Aspergillus, Penicillium, Trichoderma, Monascus. In more details, 7 of these strains were belonged to the genus Aspergillus, 1 strain to Penicillium, 1 strain to Trichoderma and 1 strain to Monascus (Table 1).

The results of $18 \mathrm{~S}$ rDNA sequence analysis of these 10 strains were in agreement with 
morphological classification, i.e. they belonged to four genera Aspergillus, Trichoderma, Monascus, and Penicillium (Table 1). A phylogenetic tree was constructed with MEGA software to overview their relationship (Figure $1)$, supporting that $18 \mathrm{~S}$ rDNA sequencing is an useful tool for fungal identification (Smit et al., 1999).
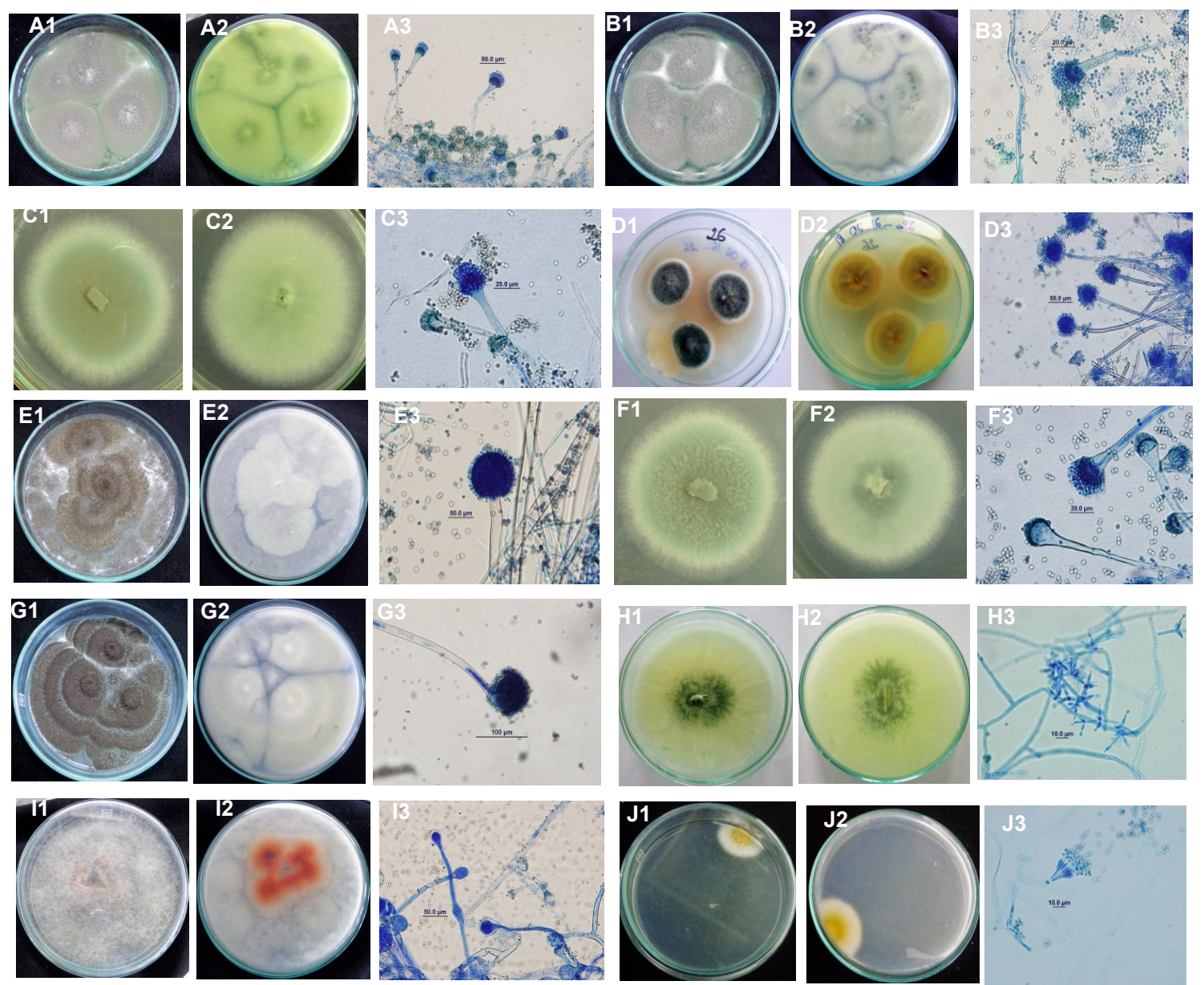

Figure 1. Colony morphology of fungi (front and reverse) on PGA plates at $32^{\circ} \mathrm{C}$ after $5-7$ days and micrographs of their conidiophore. (A): Strain I; (B) Strain II; (C) Strain III; (D) Strain IV; (E) Strain V; (F) Strain VI; (G) Strain VII; (H) Strain VIII; (I) Strain IX; (J) Strain X. Scale bars: A3= D4=E3=I3=50 $\mu$ M; B3= C3=F3=20 $\mu \mathrm{M} ; \mathrm{G} 3=100 \mu \mathrm{M} ; \mathrm{H} 3=\mathrm{H} 4=\mathrm{J} 3=10 \mu \mathrm{M}$

Table 1. Macroscopic and microscopic characteristics of the 10 fungal strains isolated from industrial scale - municipal biosolid waste composting piles in Binh Duong, Vietnam. In the table, the fungi with similar characteristics were grouped together.

\begin{tabular}{|c|c|c|c|c|c|c|c|c|c|}
\hline \multirow[b]{2}{*}{ Strain } & \multicolumn{5}{|c|}{ Macroscopic characteristics } & \multicolumn{3}{|c|}{ Microscopic characteristics } & \multirow[b]{2}{*}{ Identify } \\
\hline & $\begin{array}{l}\text { Colony } \\
\text { radius } \\
\text { after } 72 \\
\mathrm{~h}(\mathrm{~mm})\end{array}$ & Color & $\begin{array}{l}\text { Reverse } \\
\text { color }\end{array}$ & $\begin{array}{l}\text { Time of } \\
\text { first } \\
\text { observe } \\
\text { d } \\
\text { conidia } \\
\text { (h) }\end{array}$ & $\begin{array}{l}\text { Pigmentation } \\
\text { on medium }\end{array}$ & Conidiophores & $\begin{array}{l}\text { Diameter } \\
\text { of } \\
\text { conidia } \\
(\mu \mathrm{m})\end{array}$ & $\begin{array}{l}\text { Shape of } \\
\text { conidia }\end{array}$ & \\
\hline
\end{tabular}


Journal of Biotechnology 15(4): 763-770, 2017

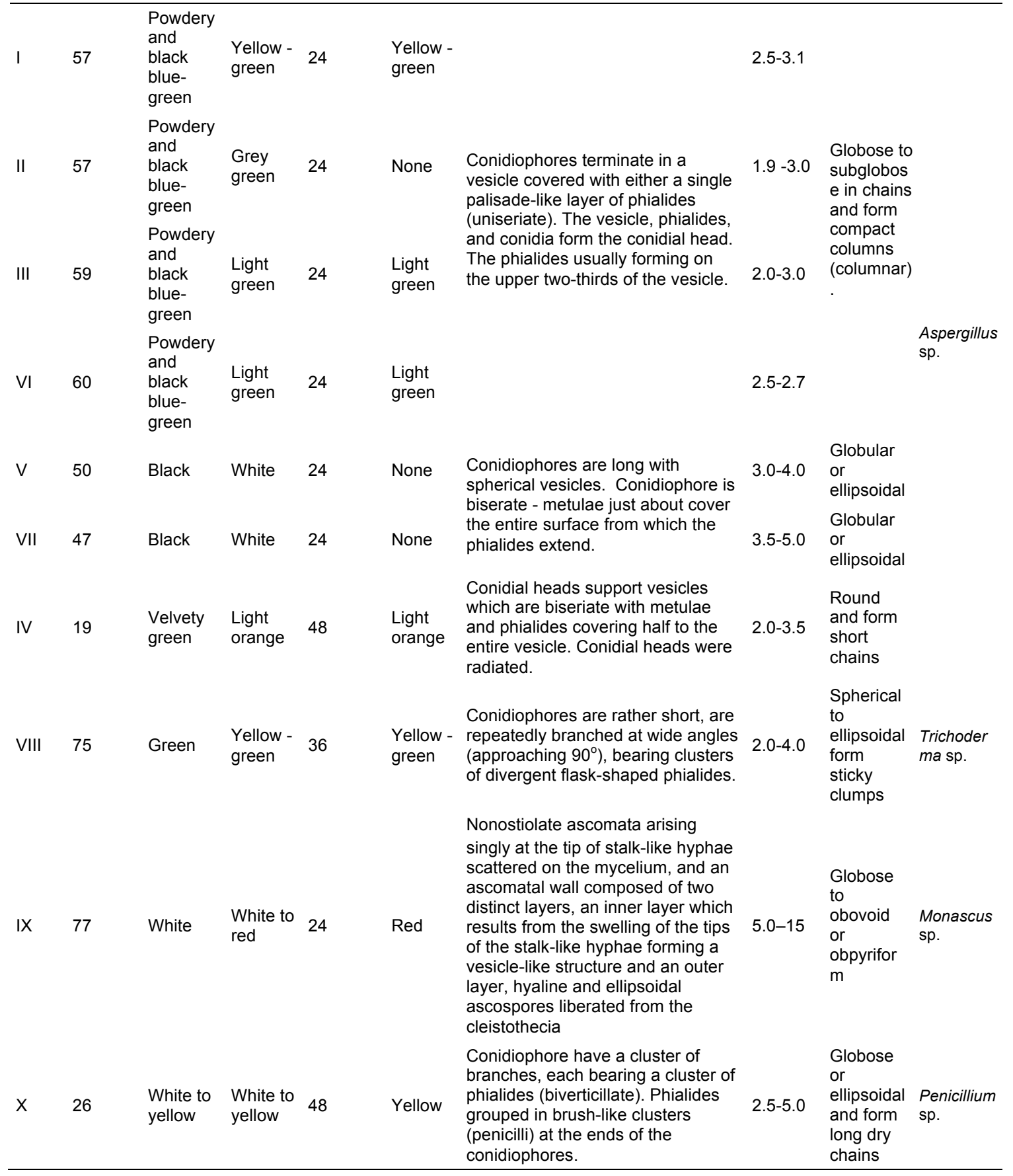


Journal of Biotechnology 15(4): 763-770, 2017

Table 2. Results of $18 \mathrm{~S}$ rDNA sequences analysis of the 10 fungal strains isolated from compost material in comparison to the available sequences on NCBI database using BLAST algorithm.

\begin{tabular}{lllll}
\hline Strain & $\begin{array}{l}\text { Length of 18S rDNA } \\
\text { sequence (bps) }\end{array}$ & Query Coverage (\%) & Identity (\%) & 18S rDNA identification \\
\hline I & 631 & $100 \%$ & $100 \%$ & Aspergillus sp. ISSF-T021 \\
II & 638 & $100 \%$ & $100 \%$ & Aspergillus sp. ISSFT-021 \\
III & 638 & $100 \%$ & $100 \%$ & Aspergillus sp. ISSFT-021 \\
IV & 659 & $99 \%$ & $99 \%$ & Aspergillus versicolor \\
V & 636 & $100 \%$ & $100 \%$ & Aspergillus sp. PSFNRH-2 \\
VI & 638 & $100 \%$ & $100 \%$ & Aspergillus fumigatus \\
VII & 644 & $100 \%$ & $100 \%$ & Aspergillus sp. CC-FB1 \\
VIII & 634 & $100 \%$ & $100 \%$ & Trichoderma sp. S1102 \\
& 665 & $100 \%$ & $99 \%$ & Monascus purpureus \\
IX & & $100 \%$ & $100 \%$ & or Monascus ruber \\
& 945 & & & Pennicillium sp. SCS-KFD08 \\
\hline
\end{tabular}

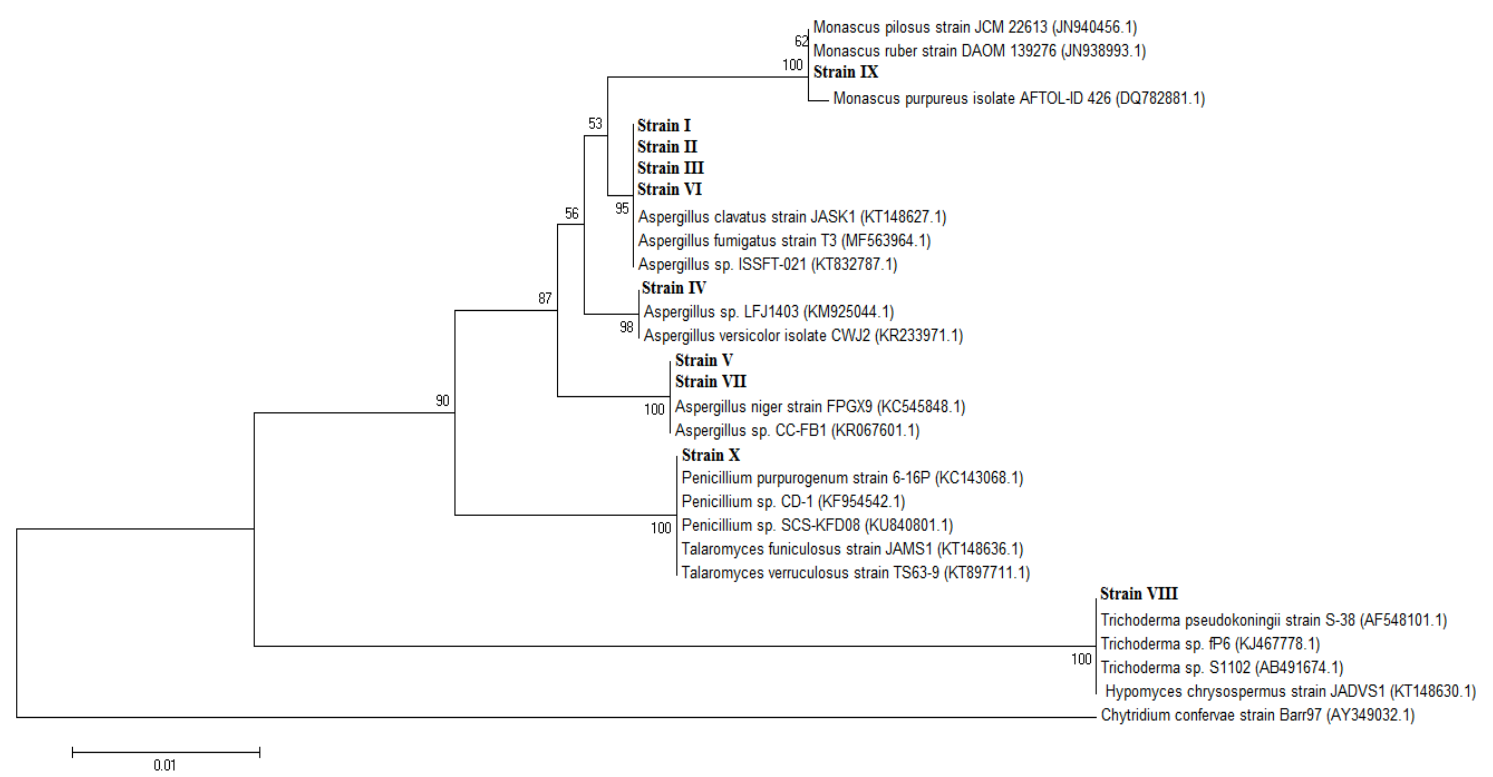

Figure 2. Phylogenetic tree was constructed with $18 \mathrm{~S}$ rDNA sequence of the isolated fungi and related species using neighbor-joining method (MEGA 6 software). Numbers at branches are bootstrap values of 1,000 replications. The scale bar is in fixed nucleotide substitution per sequence position. 


\section{DISCUSSION}

During composting process, organic materials in municipal waste is converted into useful organic manure by microorganisms, among those fungi are important because they can decompose plant derived ligno-cellulosic materials (Kohzu et al., 2005). In this study, morphological and $18 \mathrm{~S}$ rDNA classification analyses have been consistently showed that the common fungal strains in municipal biosolid waste composting process were Aspergillus, Penicillium, Monascus, and Trichoderma. Our observation was in agreement with the previous reports, indicating the abundance and important of these four fungal genera in composting process of bio-organic materials (Anastasi et al., 2005; Eida et al., 2011). The thermotolerance and capacity to degrade a wide range of organic waste of Aspergillus, Penicillium fungi may be the reasons for their dominant in bio-organic composting process (Miller, 1996).

In consistence with previous study, the data of our study showed that 7 out of the 10 fungal strains were identified as Aspergillus, suggesting that Aspergillus was the most common group in the investigated composting process (Ashraf et al., 2007). The fungi of Aspergillus genus can survive in many different environmental conditions, and possess diverse hydrolytic enzymes (amylase, protease, cellulase), therefore the fungi can degraded variety organic compounds, even complex organic compounds like lignin and cellulose, and play important roles in the composting process (Hawksworth, 2011). Besides Aspergillus, fungi of the other three genera have been also known for their ability to promote the speed and efficacy of composting process. Fungi of Trichoderma, and Penicillium genera have also been reported for participation in degrading a wide range of organic compounds in composting process. Recently, Penicillium expansum W4, a fungal strain producing ligno-cellulase, has been reported to be able to improve the quality and efficiency of composting process (Wang et al., 2011). In another study, Trichoderma atroviride has improved humic acid content in the mature compost by degradation of lignin and cellulose, xylan compounds (Maji et al., 2015). Fungi of Mucor genus have been report as the most dominant fungal genus in sawdust compost, representing 50\% (9/18) of all isolates, and have high $\beta$-glucanase, mannanase, and protease activities (Hefnawy et al., 2013) and household waste (Dehghani et al., 2012).
Beside the ability to improve the efficacy and quality of composting process, fungi also play significant roles in protection of plants against pathogenic fungi. Aydi-Ben Abdallah et al. (2014) has reported that Pythium leak disease on potato caused by Pythium ultimum was controlled by culture filtrates and organic extracts from Aspergillus spp., originated from compost. The research of Makut and Owolewa (2011) showed that Penicillium sp. and Aspergillus sp. had the ability to inhibit the fungal pathogen Candida albicans. It is well known that Trichoderma sp. have the ability to antagonize different plant pathogens such as Fusarium sp., Pythium sp., Rhizoctonia sp., and has been widely used in agriculture. Moreover, Trichoderma can enhance the plant growth and development, as well as support plants to respond to stress conditions such as drought and soil salinity.

\section{CONCLUSION}

In conclusion, the results of this study have revealed that fungi of four genera Aspergillus, Penicillium, Monascus, and Trichoderma were associated with municipal biosolid waste composting process at industrial scale in Vietnam. It is call for further study for better understanding of their roles in degradation of organic compounds in composting process, and maturation of composting materials. The understanding of composting-associated fungi is necessary for carrying out monitor and their utilization to improve the performance of industrial biosolid composting process.

Acknowledgements: This research is funded by Vietnam National University of Ho Chi Minh City (VNU-HCM) under grant number C2016-24-04/HĐKHCN. We would like to thank South Binh Duong Solid Waste Treatment Complex for supports in collecting compost samples.

\section{REFERENCES}

Anastasi A, Varese GC, Filipello Marchisio V (2005) Isolation and identification of fungal communities in compost and vermicompost. Mycologia 97(1): 33-44.

Ashraf R, Shahid, F, Ali TA (2007) Association of fungi, bacteria and actinomycetes with different composts. Pak $J$ Bot 39(6): 2141-2151.

Aydi-Ben Abdallah R, Hassine M, Jabnoun-Khiareddine H, Haouala R, DaamiRemadi M (2014) Antifungal activity 
of culture filtrates and organic extracts of Aspergillus spp . against Pythium ultimum. J Plant Ptotec 9: 17-30.

Benson HJ (2002) Microbial Applications - A Laboratory Manual in General Microbiology, 8th ed. The McGrawHill Company.

Domsch KH, Gams W, Anderson TH (1980) Compendium of soil fungi. London, England: Academic Press. 865 p.

Dehghani R, Asadi MA, Charkhloo E, Mostafaie G, Saffari M, Mousavi GA, Pourbabaei M (2012) Identification of fungal communities in producing compost by windrow method. J Environ Prot (Irvine, Calif) 3: 6167.

Eida MF, Nagaoka T, Wasaki J, Kouno K (2011) Evaluation of cellulolytic and hemicellulolytic abilities of fungi isolated from coffee residue and sawdust composts. Microbes Environ 26(3): 220-227.

Feng J, Hwang R, Chang KF, Hwang SF, Strelkov SE, Gossen BD, Zhou Q (2010) An inexpensive method for extraction of genomic DNA from fungal mycelia. Can $J$ Plant Pathol 32(3): 396-401.

Hawksworth DL (2011) Naming Aspergillus species: progress towards one name for each species. Med Mycol 49: S70-76.

Hefnawy M, Gharieb M, Nagdi OM (2013) Microbial diversity during composting cycles of rice straw. International Journal of Advanced Biological and Biomedical Research 1(3): 232-245.

Howard RL, Abotsi E, Jansen van REL, Howard S (2003) Lignocellulose biotechnology: issues of bioconversion and enzyme production. Afr J Biotechnol 2(12): 602-619.

Insam H, de Bertoldi M (2007) Microbiology of the composting process. In Diaz LF, de Bertoldi M, Bidlingmaier W, Stentiford E, eds. Compost Science and Technology. Waste Management Series: 25-48.

Kohzu A, Miyajima T, Tateishi T, Watanabe T, Takahashi
M, Wada E (2005) Dynamics of 13C natural abundance in wood decomposing fungi and their ecophysiological implications. Soil Biol Biochem 37 (9): 1598-1607.

Kumar R, Singh S, Singh OV (2008) Bioconversion of lignocellulosic biomass: biochemical and molecular perspectives. J Ind Microbiol Biotechnol 35(5): 377-391.

Maji D, Singh M, Wasnik K, Chanotiya CS, Kalra A (2015) The role of a novel fungal strain Trichoderma atroviride RVF3 in improving humic acid content in mature compost and vermicompost via ligninolytic and celluloxylanolytic activities. J Appl Microbiol 119(6): 1584-1596.

Makut MD, Owolewa OA (2011) Antibiotic-producing fungi present in the soil environment of keffi metropolis, Nasarawa state, Nigeria. Trakia Journal of Sciences 9(9): 33-39.

Miller FC (1996) Composting of municipal solid waste and its components. In Palmisano AC, Barlaz MA, eds. Microbiology of Solid Waste. CRS Press: 115-154.

Smit E, Leeflang P, Glandorf B, Van Elsas JD, Wernars K (1999) Analysis of fungal diversity in the wheat rhizosphere by sequencing of cloned PCR-amplified genes encoding 18S rRNA and temperature gradient gel electrophoresis. Appl Environ Microbiol 65(6): 2614-2621.

Song F, Tian X, Fan X, He X (2010) Decomposing ability of filamentous fungi on litter is involved in a subtropical mixed forest. Mycologia 102 (1): 20-26.

Wang HY, Fan BQ, Hu QX, Yin ZW (2011) Effect of inoculation with Penicillium expansum on the microbial community and maturity of compost. Bioresour Technol 102 (24): 11189-11193.

White TJ, Bruns T, Lee S, Taylor J (1990) Amplification and direct sequencing of fungal ribosomal RNA genes for phylogenetics. In Innis MA, Gelfand DH, Sninsky JJ, White TJ, eds. PCR Protocols: A Guide to Methods and Applications. Academic Press: 315-322.

\section{PHÂN LẬP VÀ ĐỊNH DANH CÁC VI NẤM THAM GIA VÀO QUÁ TRÌNH Ủ COMPOST CHẤT THẢ̉ RẮN SINH HOẠT ĐÔ TH!̣}

\section{Phạm Thị Thu Hằng, Lê Thị Quỳnh Trâm, Trần Phương Anh, Hồ Tô Thị Khải Mùi, Đặng Nguyễn Thảo Vi, Đinh Hoàng Đăng Khoa}

Viện Môi truờng và Tài nguyên, Đại học Quốc gia Thành phố Hồ Chỉ Minh

\section{TÓM TẮT}

Trong quá trình ủ compost, các chất thải rắn có nguồn gốc sinh học sẽ bị phân hủy bởi các vi sinh vật, tạo ra carbon dioxide, nước, nhiệt và các chất mùn (compost). Trong các vi sinh vật, nhóm vi nấm có vai trò quan trọng trong việc phân giải các hợp chất bền vững như cellulose, lignin và các vật liệu khác. Mục tiêu của nghiên cứu này là phân lập và xác định các nhóm vi nấm tham gia vào quá trình ủ compost chất thải rắn sinh học đô thị ở quy mô công nghiệp tại Việt Nam. Chúng tôi đã quan sát thấy có 10 chủng vi nấm có sự khác biệt 
về hình thái hiện diện trong quá trình ủ compost, các chủng vi nấm này sau đó được định danh dựa trên các phân tích chi tiểt về hình thái và trình tự $18 \mathrm{~S}$ rDNA của chúng. Kết quả thí nghiệm cho thấy các chủng vi nấm chiếm ưu thế thuộc về bốn chi khác nhau bao gồm Aspergillus, Penicillium, Monascus và Trichoderma. Các kết quả này sẽ là dữ liệu tham khảo hữu ích cho các phân tích sâu hơn về sự đa dạng và chức năng của các vi nấm trong quá trình phân hủy chất thải rắn sinh học đô thị ở Việt Nam.

Tù khóa: Chất thải rắn hữu co, phân compost, đa dạng sinh học vi nấm, quy mô công nghiệp, phân loại hình thái, $18 S$ rDNA. 